Supporting Information

\title{
Photodegradation of myrigalone A, an allelochemical from Myrica gale: photoproducts and effect of terpenes
}

\author{
Amina Khaled ${ }^{1}$, Mohamad Sleiman ${ }^{1}$, Etienne Darras ${ }^{1}$, Aurélien Trivella ${ }^{2}$, Cédric Bertrand ${ }^{3}$, \\ Nicolas Inguimbert ${ }^{3}$, Pascale Goupil ${ }^{5}$, Claire Richard ${ }^{1 *}$
}

(1) Université Clermont Auvergne, CNRS, SIGMA Clermont, Institut de Chimie de Clermont-Ferrand, F-63000 Clermont-Ferrand, France

(2) UMR CNRS 5805 EPOC - OASU, Equipe LPTC, IUT de Périgueux, Rue du Doyen Lajugie, 24000 Périgueux, FRANCE

(3) USR 3278 CRIOBE, PSL Research University, EPHE-UPVD-CNRS, Université de Perpignan Via Domitia, Laboratoire d'Excellence « CORAIL ». Bâtiment T, 58 avenue P. Alduy, 66860 Perpignan, France.

(4) AkiNaO SAS, F-66860 Perpignan, France

(5) Université Clermont Auvergne, INRA, PIAF, F-63000 Clermont-Ferrand, France 
Scheme SI-1: Synthesis of myrigalone A

Method 1:<smiles>O=C(Cl)CCc1ccccc1</smiles>

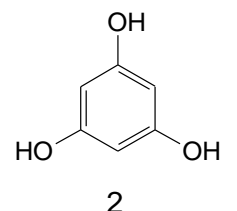

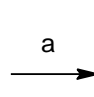

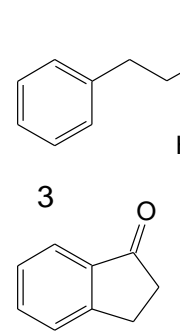

4

a) $\mathrm{AlCl}_{3}, \mathrm{CH}_{2} \mathrm{Cl}_{2}, 0^{\circ} \mathrm{C}, 5 \mathrm{~h}$; b) tBuOK, Mel, $\mathrm{MeOH}$ reflux $20 \mathrm{~h}$

3-phenyl-1-(2,4,6-trihydroxyphenyl)propan-1-one $\quad(3): \quad 1.5 \quad \mathrm{~mL} \quad(10 \mathrm{mmol}) \quad$ of 3phenylpropanoyl chloride (1) was added dropwise at $0^{\circ} \mathrm{C}$ to $1.26 \mathrm{~g}(10 \mathrm{mmol})$ of benzene-1,3,5triol (2) and $2.9 \mathrm{~g}(22 \mathrm{mmol})$ of aluminium trichloride in $20 \mathrm{~mL}$ anhydrous dichlormethane. After $3 \mathrm{~h}$ stirring the reaction is quenched with $50 \mathrm{~mL}$ of water, the resulting mixture is extracted with ethyl acetate $(3 \times 100 \mathrm{~mL})$. The resulting organic layers are pooled, concentrated delivering $2.1 \mathrm{~g}$ of a crude. Separation of compounds $\mathbf{3}$ and $\mathbf{4}$ on silica gel using a 5/1 mixture of cyclohexane/ethylacetate delivers $1 \mathrm{~g}(7 \mathrm{mmol})$ of indanone $(4)$ and $0.6 \mathrm{~g}(2.3 \mathrm{mmol}, 23 \%)$ of 3-phenyl-1-(2,4,6-trihydroxyphenyl)propan-1-one (3).

${ }^{1} \mathrm{H}$ NMR (DMSO- $\left.d_{6}\right): \delta(\mathrm{ppm}) 2.87(2 \mathrm{H}, \mathrm{t}, J=8.15 \mathrm{~Hz}), 3.28(2 \mathrm{H}, \mathrm{t}, J=8.15 \mathrm{~Hz}), 5.80(2 \mathrm{H}, \mathrm{s})$, $7.22(1 \mathrm{H}, \mathrm{tt}, J=1.83 \mathrm{~Hz}, J=6.96 \mathrm{~Hz}), 10.34(1 \mathrm{H}, \mathrm{s}), 12.21(2 \mathrm{H}, \mathrm{s}) .{ }^{13} \mathrm{C}$ NMR (DMSO- $\left.d_{6}\right): \delta$ (ppm) 30.2, 45.0, 94.67, 103.7, 125.8, 128.3, 128.4, 141.7, 164.2, 164.6, 203,9.

Myrigalone A: $0.174 \mathrm{~g}(1.6 \mathrm{mmol})$ of potassium tertiobutylate are added to $0.1 \mathrm{~g}(0.34 \mathrm{mmol})$ of compound 3 in $10 \mathrm{~mL}$ methanol at $0^{\circ} \mathrm{C}$. After 5 min stirring $72 \mu \mathrm{L}(1.6 \mathrm{mmol})$ of methyliodide was added and the resulting mixture was heated under reflux for three hours. After cooling the reaction mixture was diluted with $30 \mathrm{~mL}$ water, acidified at $\mathrm{pH} 3$ with $1 \mathrm{~N} \mathrm{HCl}$ and extracted with ethylacetate $(4 \times 20 \mathrm{~mL})$. The resulting organic layers are pooled, dried over $\mathrm{MgSO}_{4}$ filtered and concentrated. Crude purification on silica gel using a 1/1 mixture of cyclohexane/ethylacetate afforded $0.15 \mathrm{~g}(1.2 \mathrm{mmol}, 75 \%)$ of myrigalone A.

${ }^{1} \mathrm{H} \mathrm{NMR}\left(\mathrm{CDCl}_{3}\right): \delta(\mathrm{ppm}) 1.37$ and $1.49(6 \mathrm{H}, 2 \mathrm{x} \mathrm{s}), 1.82$ and $1.87(3 \mathrm{H}, 2 \mathrm{x} \mathrm{s}), 2.96(2 \mathrm{H}, \mathrm{m})$, 3.34 and $3.50(3 \mathrm{H}, \mathrm{tt}, 2 \mathrm{x} \mathrm{m}), 7.11(1 \mathrm{H}, \mathrm{m}), 7.26(4 \mathrm{H}, \mathrm{m}) .{ }^{13} \mathrm{C} \mathrm{NMR}\left(\mathrm{CDCl}_{3}\right): \delta(\mathrm{ppm}) 7.8,24.7$, $30,9,41.8,48.2$, 102,9, 105,9, 126,0, 128.4, 128.6, 141.1, 141.3, 172.9, 189.2, 196.8, 202.9. 
Method 2:

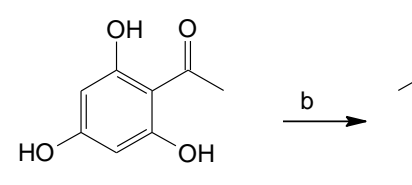

5

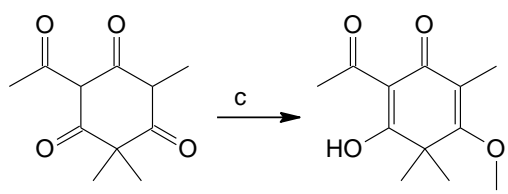

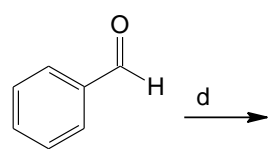

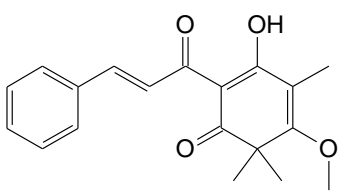

10

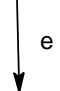<smiles>COC1=C(C)C(O)=C(C(=O)CCc2ccccc2)C(=O)C1(C)C</smiles><smiles>CC1C(=O)C(C(=O)CCc2ccccc2)C(=O)C(C)(C)C1=O</smiles>

b) tBuOK, Mel, $\mathrm{MeOH}$ reflux $20 \mathrm{~h}$; c) trimethylsilyldiazomethane (4 eq), $\mathrm{AcOEt}, \mathrm{MeOH},-78^{\circ} \mathrm{C}, 5 \mathrm{~h}$; d) $\mathrm{KOH}, \mathrm{EtOH}$, $20^{\circ} \mathrm{C}, 24 \mathrm{~h}$; e) $\mathrm{H}_{2}, \mathrm{Pd} / \mathrm{C}, 1 \mathrm{~atm}, 2 \mathrm{~h}$; e) $\mathrm{HCl}$, acetone, $\mathrm{MeOH}$, reflux, $2 \mathrm{~h}$.

4-acetyl-2,2,6-trimethylcyclohexane-1,3,5-trione (6): $9.17 \mathrm{~g}(79.3 \mathrm{mmol})$ of potassium tertiobutylate are added to $4.08 \mathrm{~g}$ (21.5 mmol) of 1-(2,4,6-trihydroxyphenyl)ethanone (5) in 180 $\mathrm{mL}$ methanol at $0^{\circ} \mathrm{C}$. After $5 \mathrm{~min}$ stirring $4.45 \mathrm{~mL}(71.1 \mathrm{mmol})$ of methyliodide was added and the resulting mixture was heated under reflux for three hours. After cooling the reaction mixture was acidified at $\mathrm{pH} 3$ with $1 \mathrm{~N} \mathrm{HCl}$. The reaction mixture is concentrated under reduced pressure to two third and extracted with ethylacetate $(4 \times 40 \mathrm{~mL})$. The resulting organic layers are pooled, dried over $\mathrm{MgSO}_{4}$ filtered and concentrated. Purification of the crude on silica gel using dichloromethane afforded $2.7 \mathrm{~g}$ (12.8 mmol, 60\%) of compound 6 .

${ }^{1} \mathrm{H}$ NMR $\left(\mathrm{CDCl}_{3}\right)$ : Only the peaks of the most abundant tautomer are given $\delta(\mathrm{ppm}) 1.28(6 \mathrm{H}$, s), $1.78(3 \mathrm{H}, \mathrm{s}), 2.46(3 \mathrm{H}, \mathrm{s}) .{ }^{13} \mathrm{C} \mathrm{NMR}\left(\mathrm{CDCl}_{3}\right): \delta(\mathrm{ppm}) 7.8,24.8,28.3,48.7,102.3,105.6$, $176,5,189.4,196.5,199.9$.

2-acetyl-3-hydroxy-5-methoxy-4,4,6-trimethylcyclohexa-2,5-dien-1-one (8): $42.1 \mathrm{~mL}$ of a 2M trimethylsilyldiazomethane solution in hexane is added dropwise at $-20^{\circ} \mathrm{C}$ to a stirred solution of compound (6) in a $2 / 1$ mixture of acetonitrile/methanol $(70 \mathrm{~mL})$. The resulting orange solution is stirred overnight at $4^{\circ} \mathrm{C}$. After quenching of the reaction with acetic acid $(25 \mathrm{~mL})$ and elimination of the solvent under reduced pressure, the compound is purified on silica gel with cyclohexane/ethylacetate $9 / 1$ as eluent, yielding after concentration of the fractions $2.2 \mathrm{~g}$ (9.8 mmol, $45 \%)$ of compound 8 .

${ }^{1} \mathrm{H}$ NMR $\left(\mathrm{CDCl}_{3}\right)$ : Only the peaks of the most abundant tautomer are given $\delta(\mathrm{ppm}) 1.35(6 \mathrm{H}$, s), $1.95(3 \mathrm{H}, \mathrm{s}), 2.59(3 \mathrm{H}, \mathrm{s}), 3.92(3 \mathrm{H}, \mathrm{s}) .{ }^{13} \mathrm{C} \mathrm{NMR}\left(\mathrm{CDCl}_{3}\right): \delta(\mathrm{ppm}) 9.7,24.2,24.4,28.1$, $50.3,62.2,107,3,112,1,177,0,190,3,197,3,201.4$.

3-hydroxy-5-methoxy-4,6,6-trimethyl-2-[(2E)-3-phenylprop-2-enoyl]cyclohexa-2,4-dien-1one (10): $60 \mathrm{~mL}$ of a $50 \%$ aqueous solution of $\mathrm{KOH}$ is added to a stirred solution of $2 \mathrm{~g} \mathrm{(8.9}$ 
mmol) of compound 8 in $50 \mathrm{~mL}$ ethanol. $1 \mathrm{~mL}(9.8 \mathrm{mmol})$ of freshly distillated benzaldehyde (9) is added to the previous solution and stirred at $25^{\circ} \mathrm{C}$ for $18 \mathrm{~h}$. After acidification to $\mathrm{pH} 1$ with $\mathrm{HCl} 10 \mathrm{~N}$ the aqueous phase is extracted with dichloromethane $(3 \mathrm{x} 40 \mathrm{~mL})$, the organic layers are pooled, dried over $\mathrm{MgSO}_{4}$ and concentrated. Purification on silica gel with cyclohexane/ethylacetate $9 / 1$ afforded $1.9 \mathrm{~g}(6.1 \mathrm{mmol}, 69 \%)$ of compound $\mathbf{1 0}$.

${ }^{1} \mathrm{H} \mathrm{NMR}\left(\mathrm{CDCl}_{3}\right)$ : Only the peaks of the most abundant tautomer are given $\delta(\mathrm{ppm}) 1.36(6 \mathrm{H}$, s), $1.98(3 \mathrm{H}, \mathrm{s}), 3.94(3 \mathrm{H}, \mathrm{s}), 7.38(3 \mathrm{H}, \mathrm{m}), 7.65(2 \mathrm{H}, \mathrm{m}), 7.92(1 \mathrm{H}, \mathrm{d}, J=15.6 \mathrm{~Hz}), 8.32(1 \mathrm{H}$, $\mathrm{d}, J=15.6 \mathrm{~Hz}) .{ }^{13} \mathrm{C} \mathrm{NMR}\left(\mathrm{CDCl}_{3}\right): \delta(\mathrm{ppm}) 9.9,24.5,50.5,62.2,106.7,113.7,123.3,128.9$, $129.1,130.7,135.3,144.9,176.7,187.3,192.5,198.1$.

3-hydroxy-5-methoxy-4,6,6-trimethyl-2-[3-phenylpropanoyl]cyclohexa-2,4-dien-1-one (11): $100 \mathrm{mg}(0.32 \mathrm{mmol})$ of compound 10 with $10 \mathrm{mg}$ of $\mathrm{Pd} / \mathrm{C} 10 \%$ in $7 \mathrm{~mL}$ methanol are stirred under hydrogen for $3 \mathrm{~h}$ to yield quantitatively after filtration and concentration of the filtrate the compound presenting a reduced double bond. This compound is used without purification in the next step.

${ }^{1} \mathrm{H} \mathrm{NMR}\left(\mathrm{CDCl}_{3}\right)$ : Only the peaks of the most abundant tautomer are given $\delta(\mathrm{ppm}) 1.29(6 \mathrm{H}$, s), $1.95(3 \mathrm{H}, \mathrm{s}), 2.95(2 \mathrm{H}, \mathrm{m}), 3.65(2 \mathrm{H}, \mathrm{m}), 3.94(3 \mathrm{H}, \mathrm{s}), 7.15(1 \mathrm{H}, \mathrm{m}), 7.25(4 \mathrm{H}, \mathrm{m}) .{ }^{13} \mathrm{C} \mathrm{NMR}$ $\left(\mathrm{CDCl}_{3}\right): \delta$ (ppm) 9.7, 24.3, 24.4, 30.5, 41.8, 50.4, 62.2, 109.3, 112.0, 126.0, 128.4, 128.6, $141.2,170.5,177.0,190.1,203.4$.

Myrigalone A: $100 \mathrm{mg}$ of compound 11 is dissolved in acetone/methanol 2/1 $3 \mathrm{~mL}$ and $1 \mathrm{~mL}$ $37 \% \mathrm{HCl}$ is added to the mixture. The resulting solution is refluxed for $2 \mathrm{~h}$, cooled at $25^{\circ} \mathrm{C}$, diluted with $20 \mathrm{~mL}$ water and extracted with ethylacetate $(3 \times 10 \mathrm{~mL})$. After concentration, crude purification on silica gel using a 1/1 mixture of cyclohexane/ethylacetate afforded $36 \mathrm{mg}$ $(0.12 \mathrm{mmol}, 37,5 \%)$ of myrigalone A with identical spectra to the compound obtained by method 1 . 
${ }^{1} \mathrm{H}$ NMR spectra of compound $\mathbf{3}$

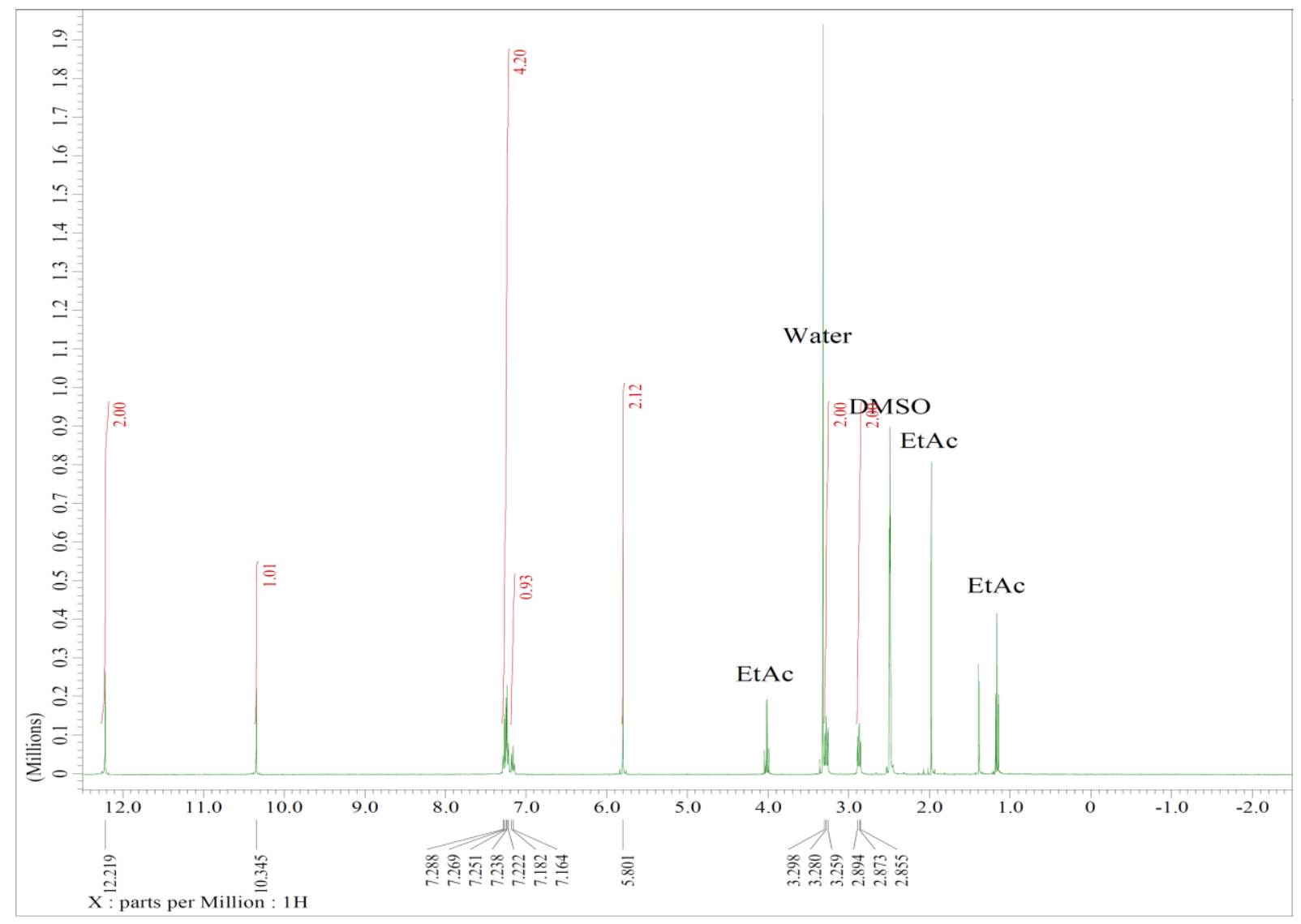

${ }^{13} \mathrm{C}$ NMR spectra of compound $\mathbf{3}$

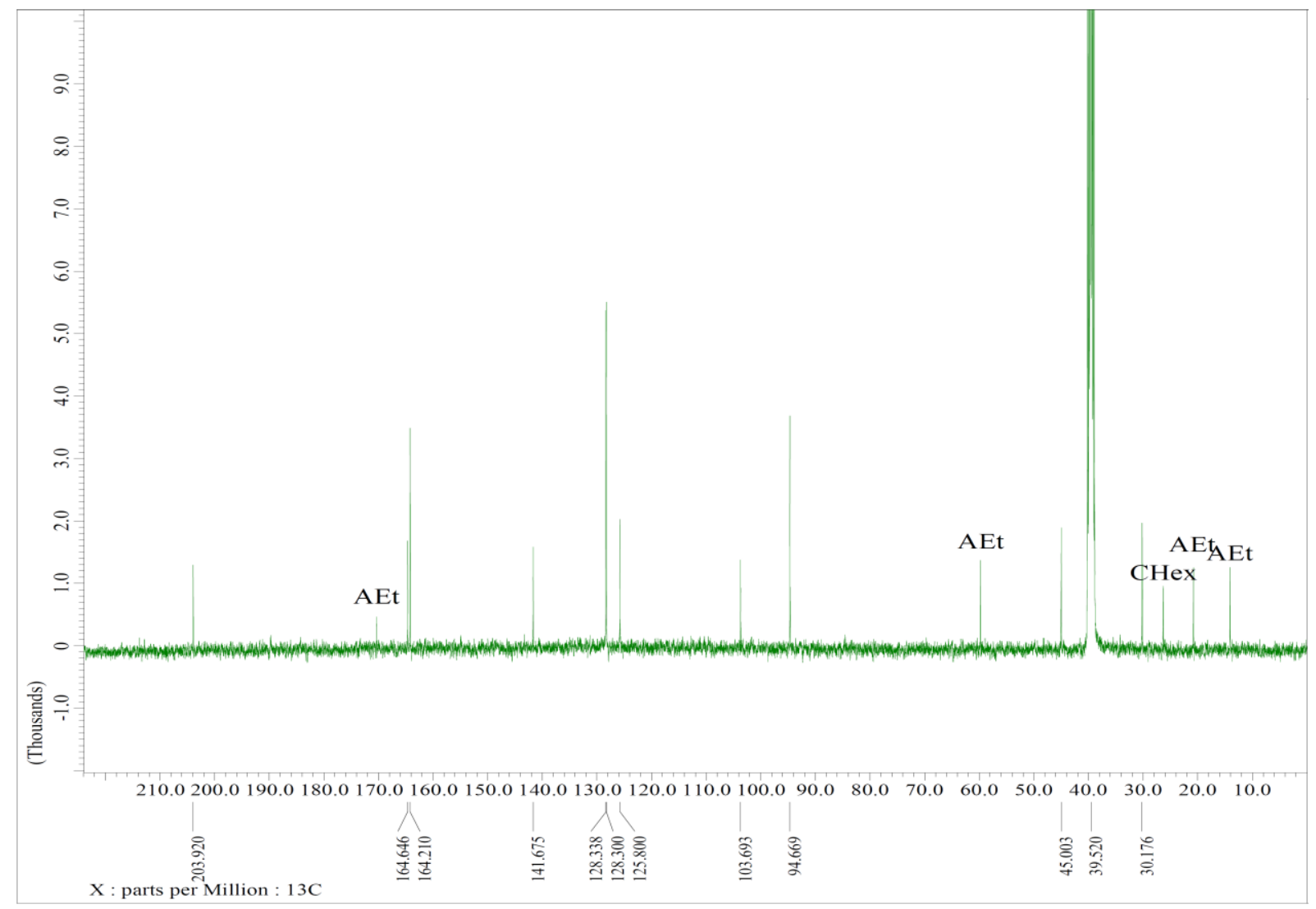


${ }^{1} \mathrm{H}$ NMR spectra of Myrigalone A

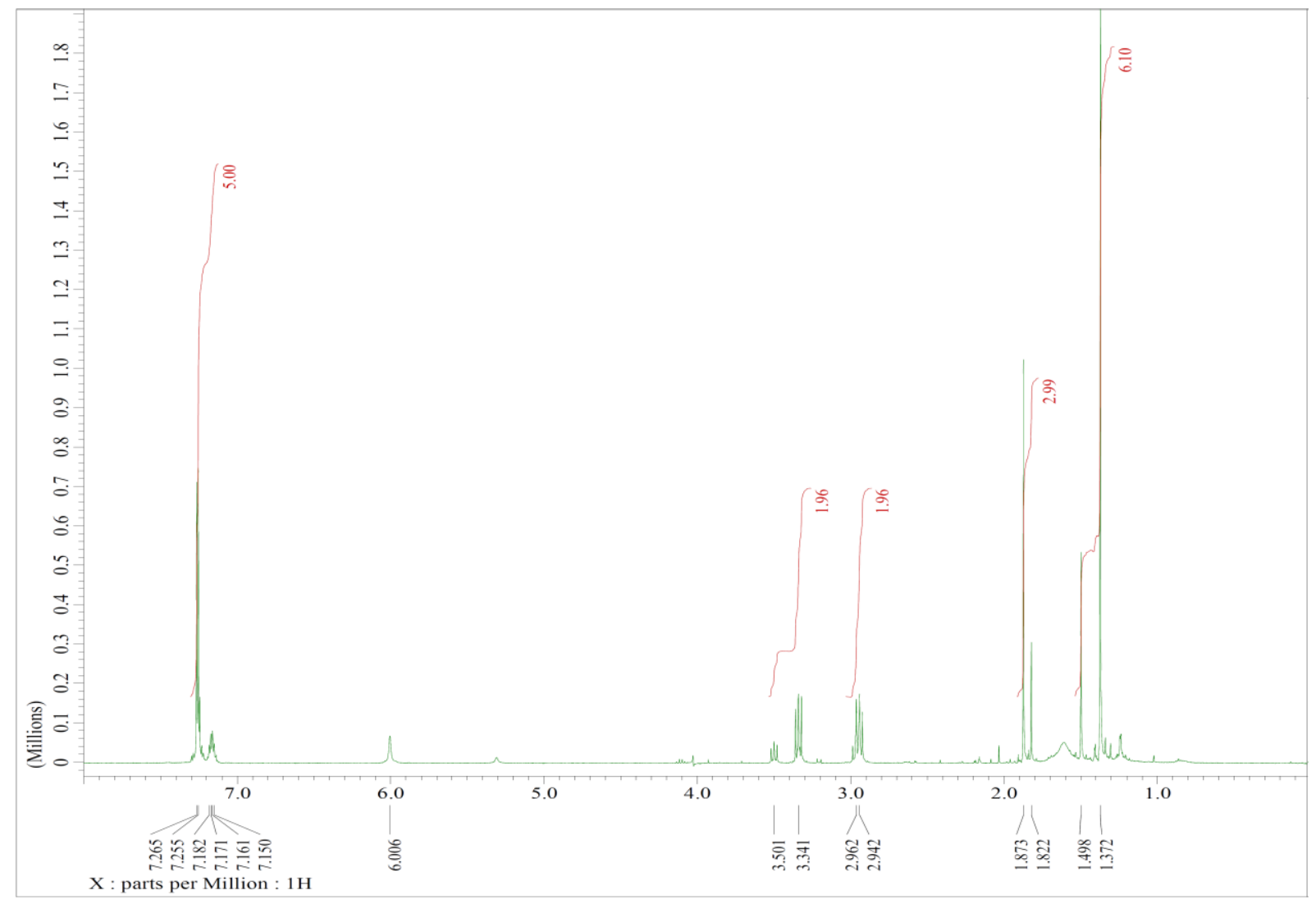

${ }^{13} \mathrm{C}$ NMR spectra of Myrigalone A

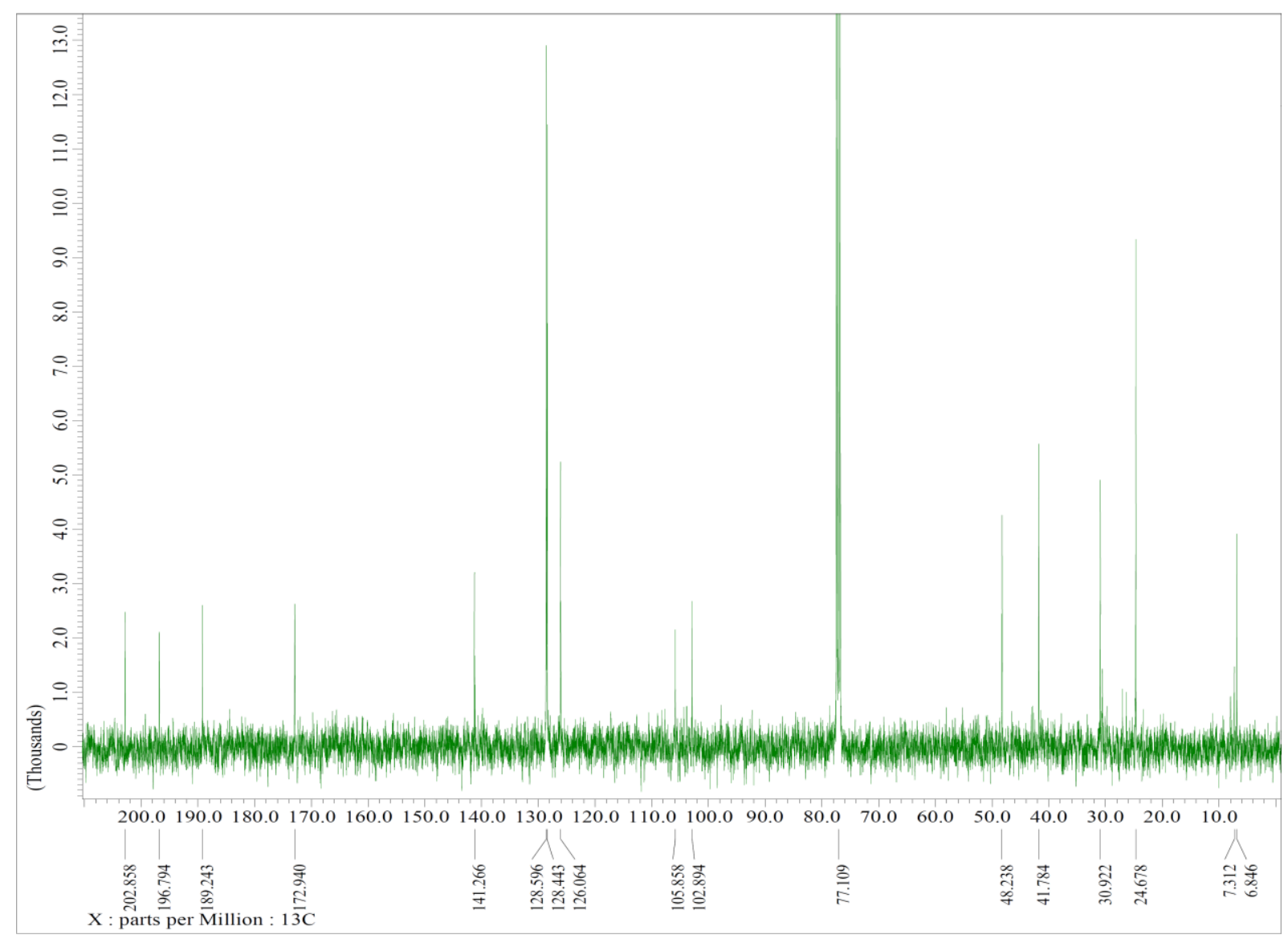


${ }^{1} \mathrm{H}$ NMR spectra of compound 6

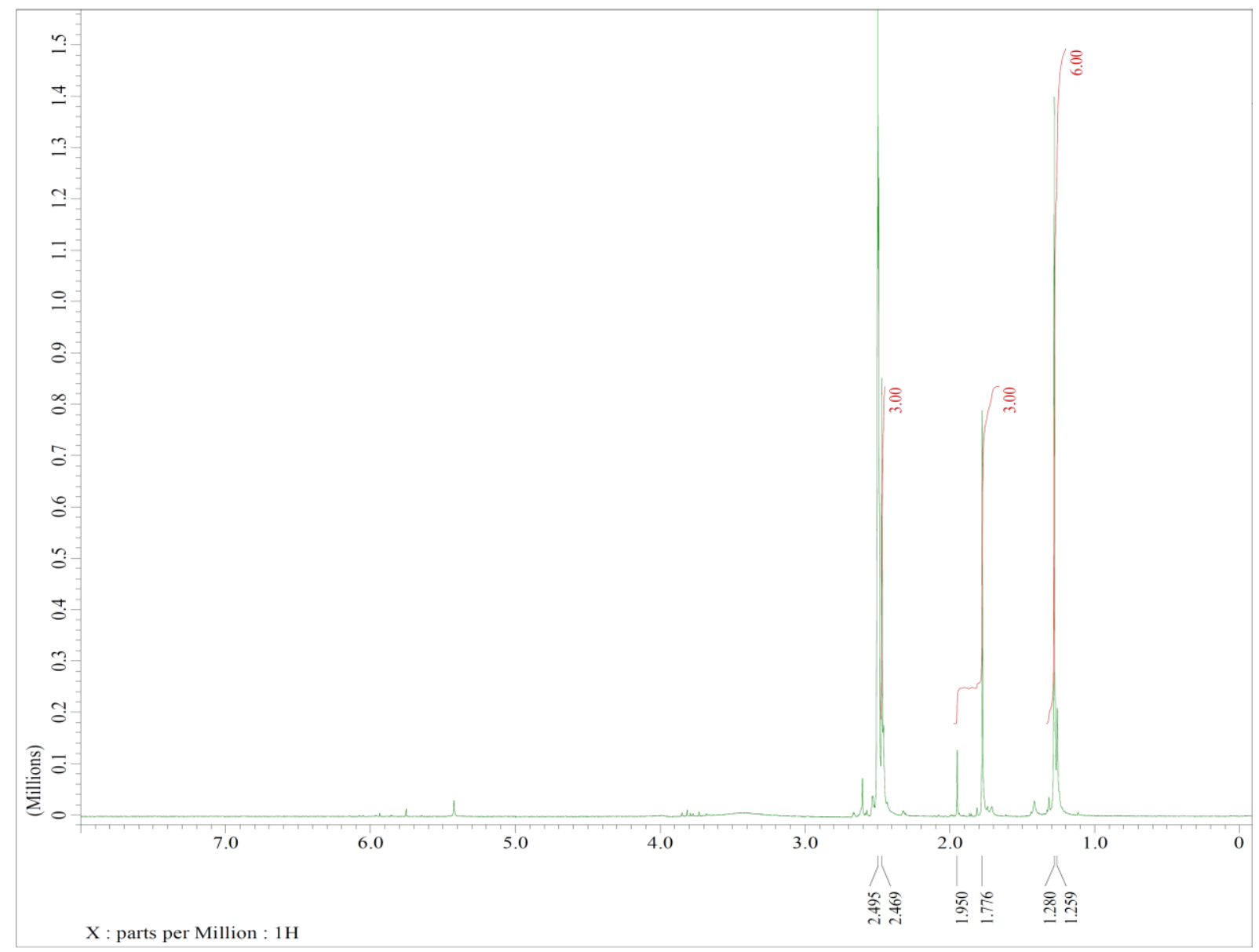

${ }^{13} \mathrm{C}$ NMR spectra of compound 6

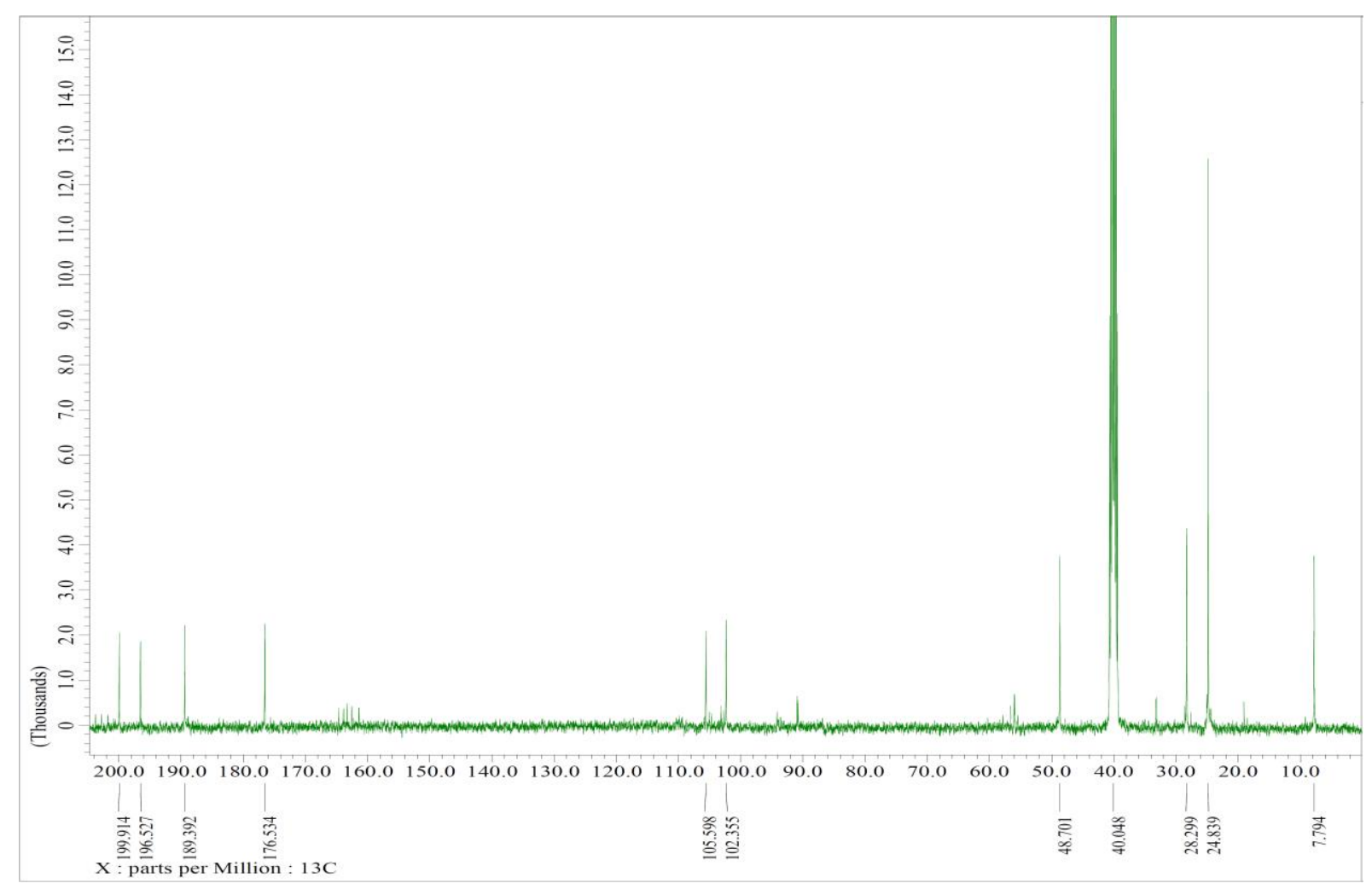


${ }^{1}$ H NMR spectra of compound 8

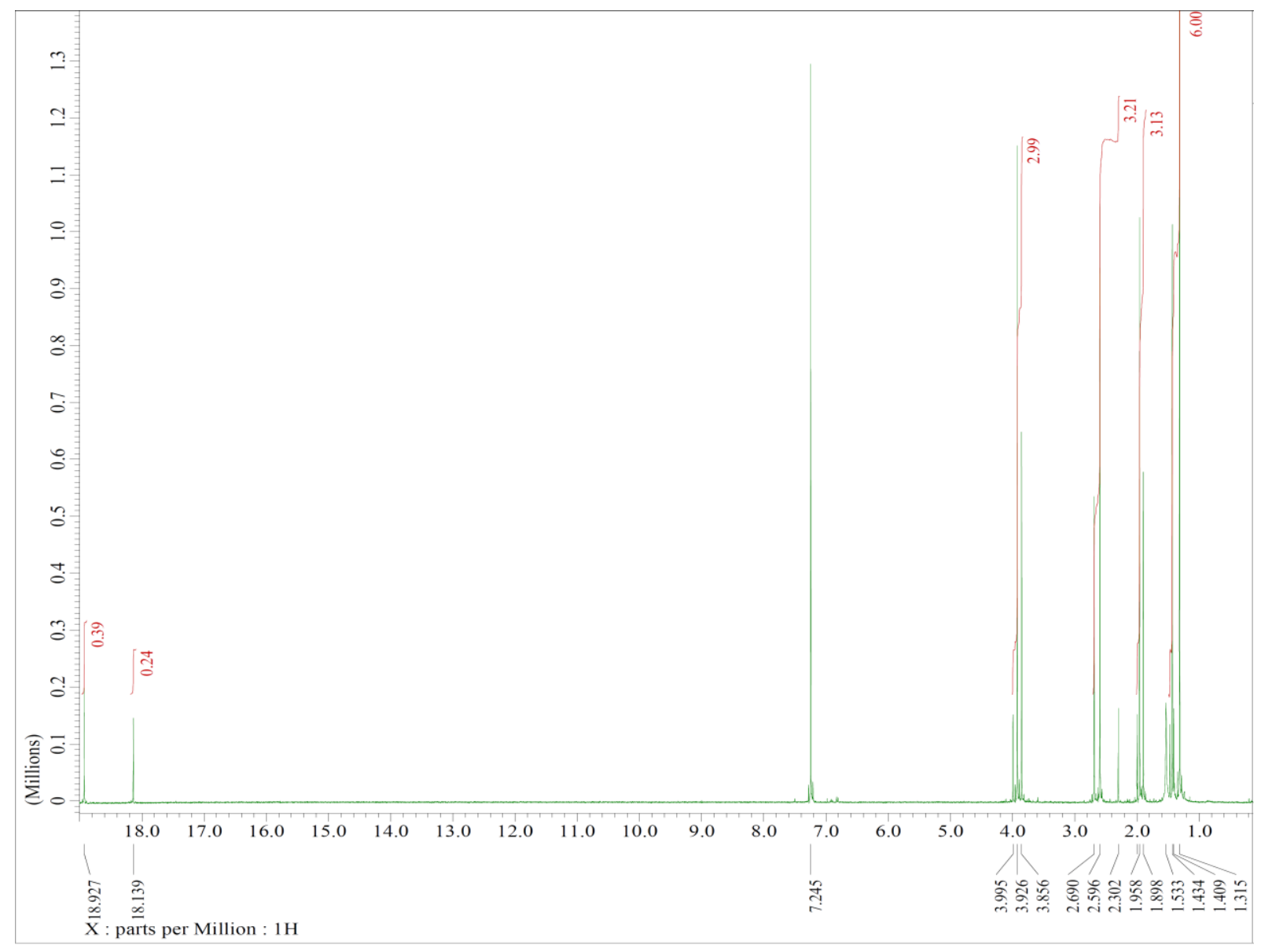

${ }^{13} \mathrm{C}$ NMR spectra of compound $\mathbf{8}$

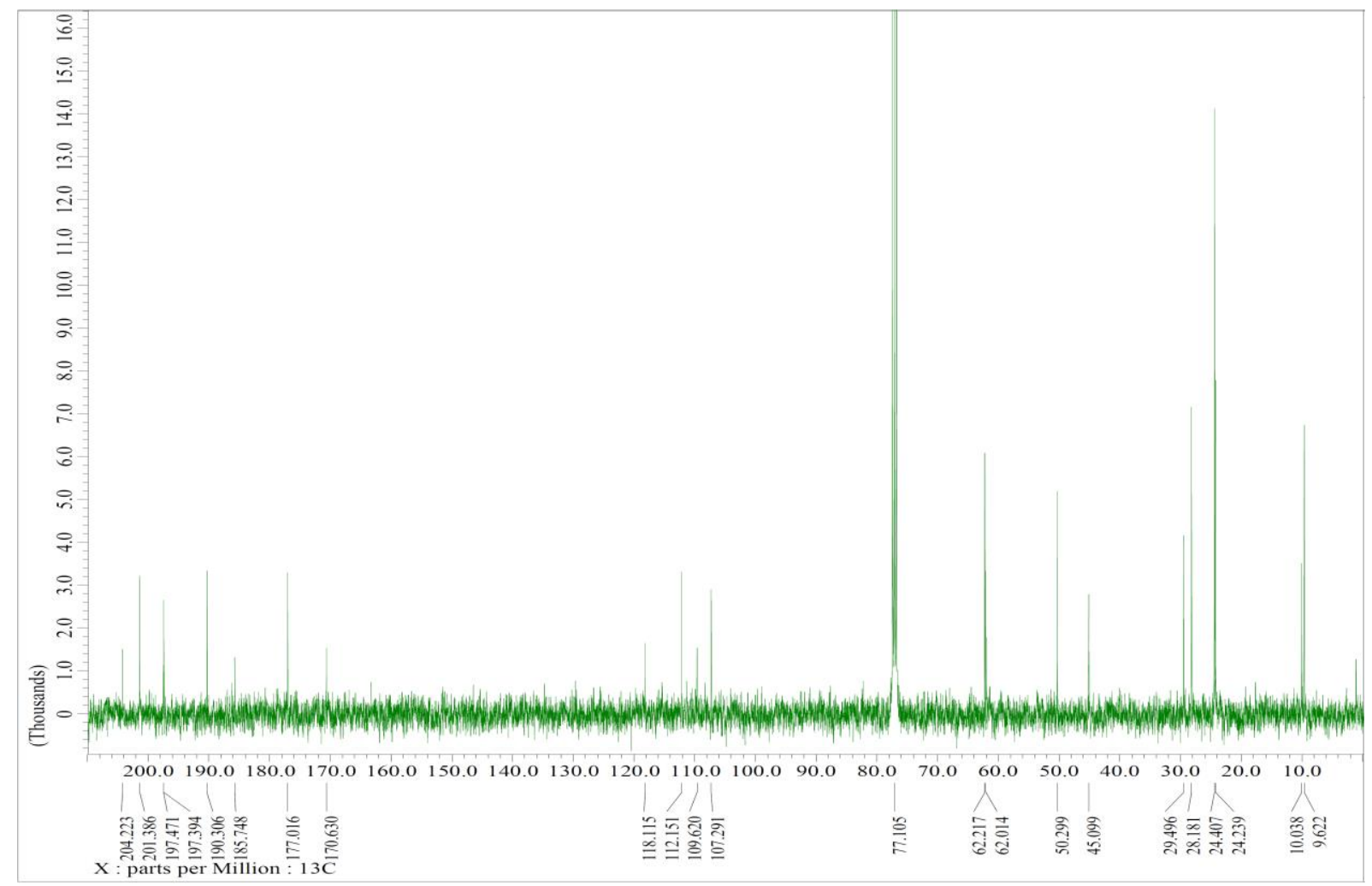


${ }^{1} \mathrm{H}$ NMR spectra of compound $\mathbf{1 0}$

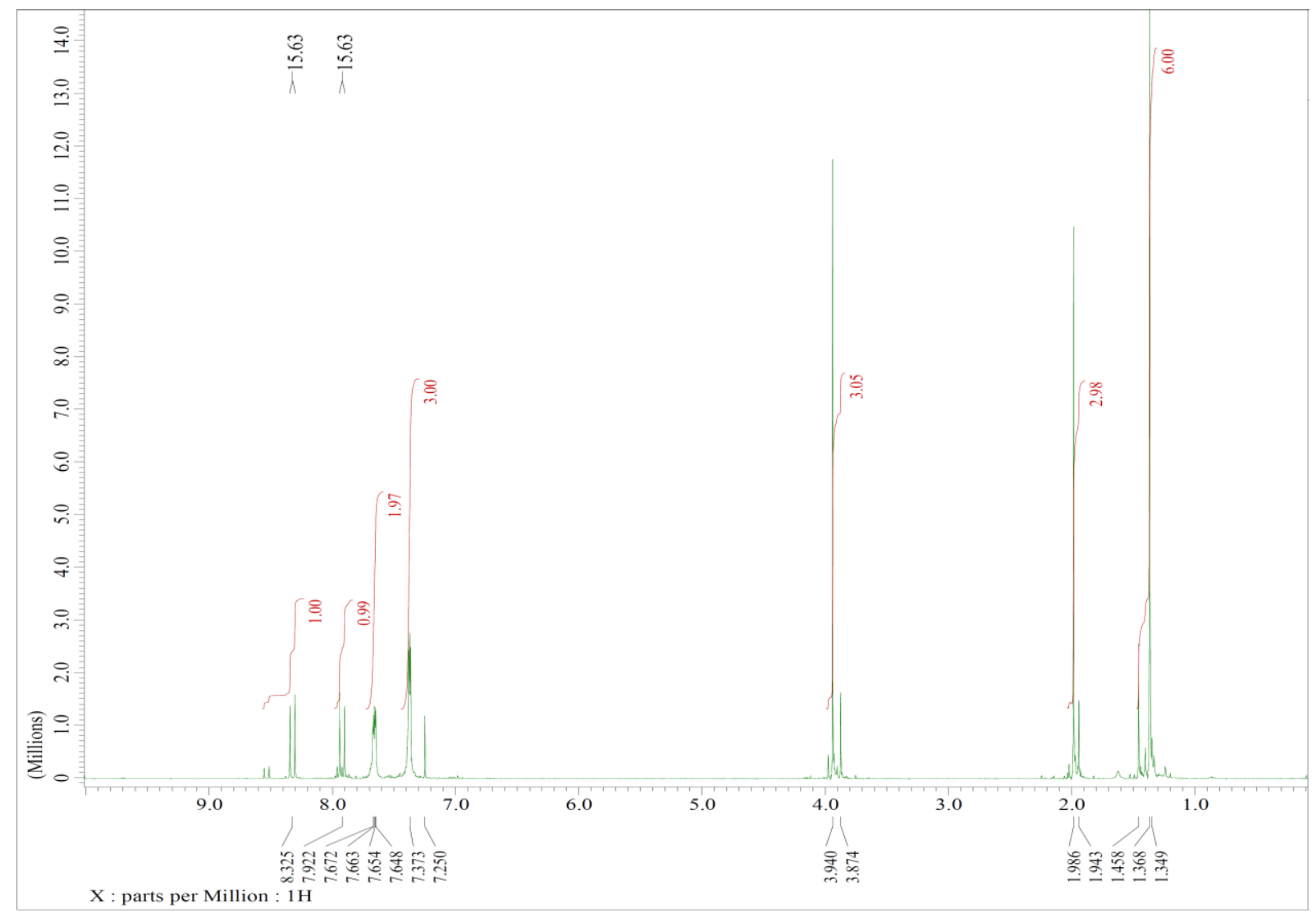

${ }^{13} \mathrm{C}$ NMR spectra of compound $\mathbf{1 0}$

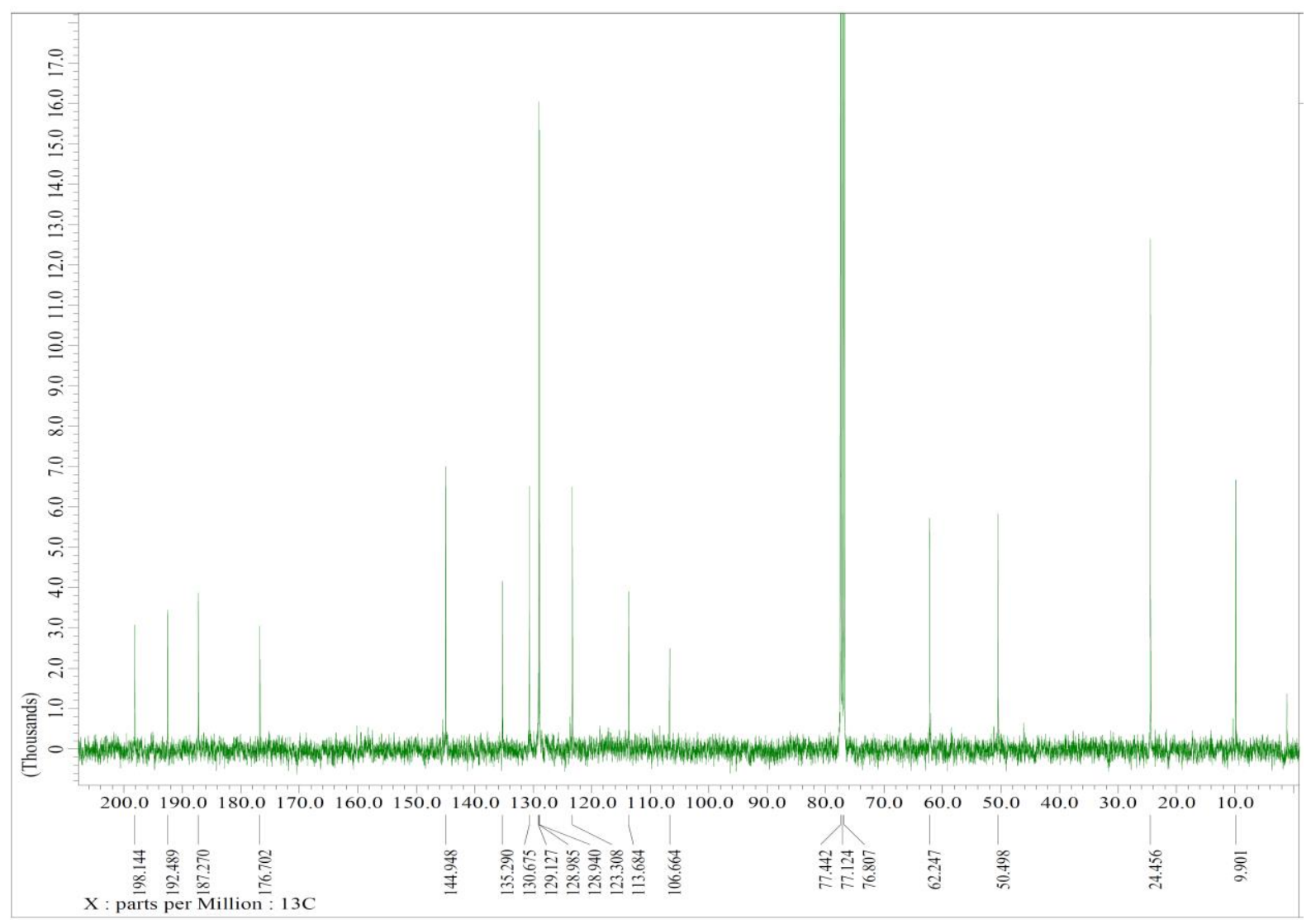


${ }^{1} \mathrm{H}$ NMR spectra of compound $\mathbf{1 1}$

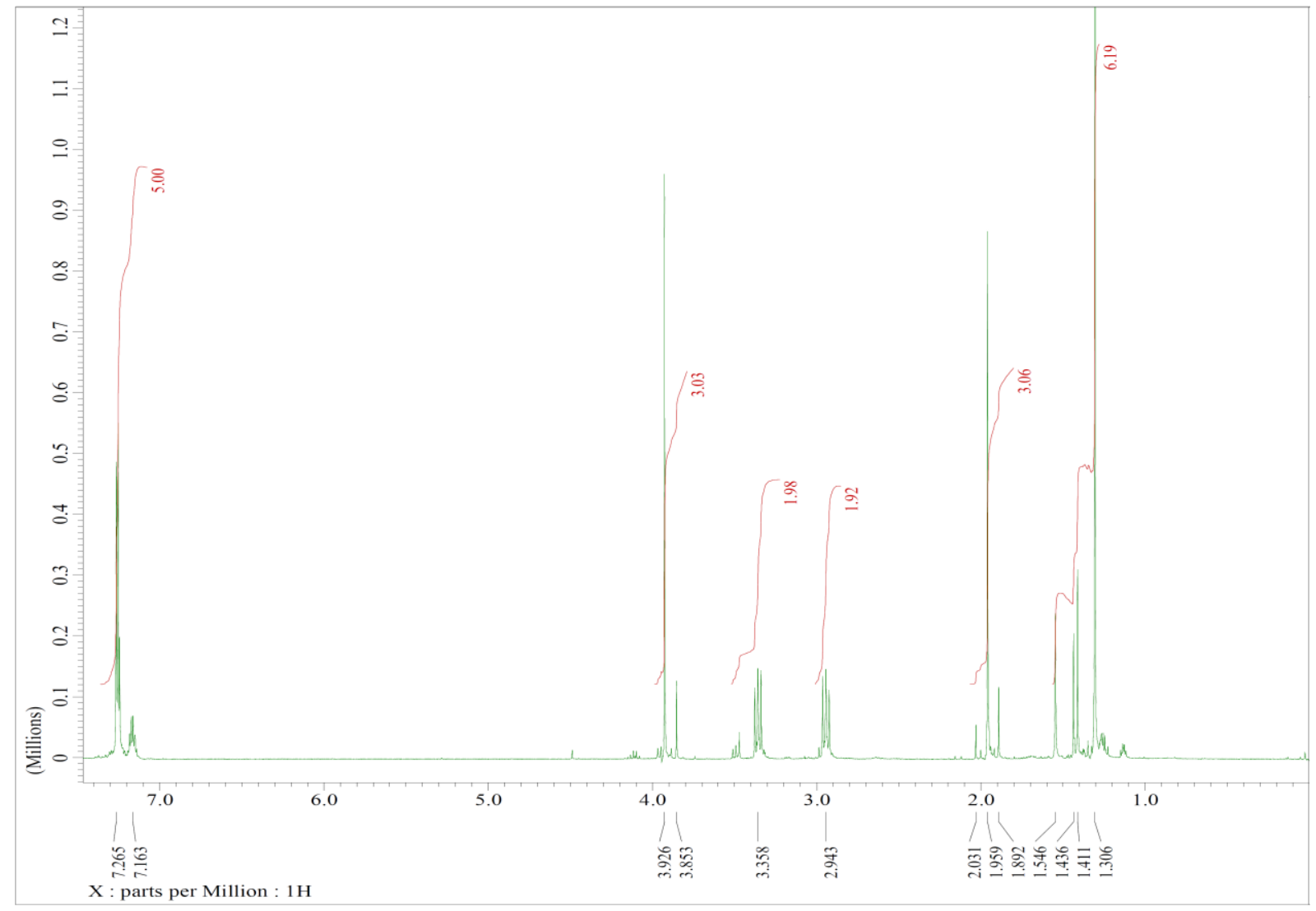

${ }^{13} \mathrm{C}$ NMR spectra of compound $\mathbf{1 1}$

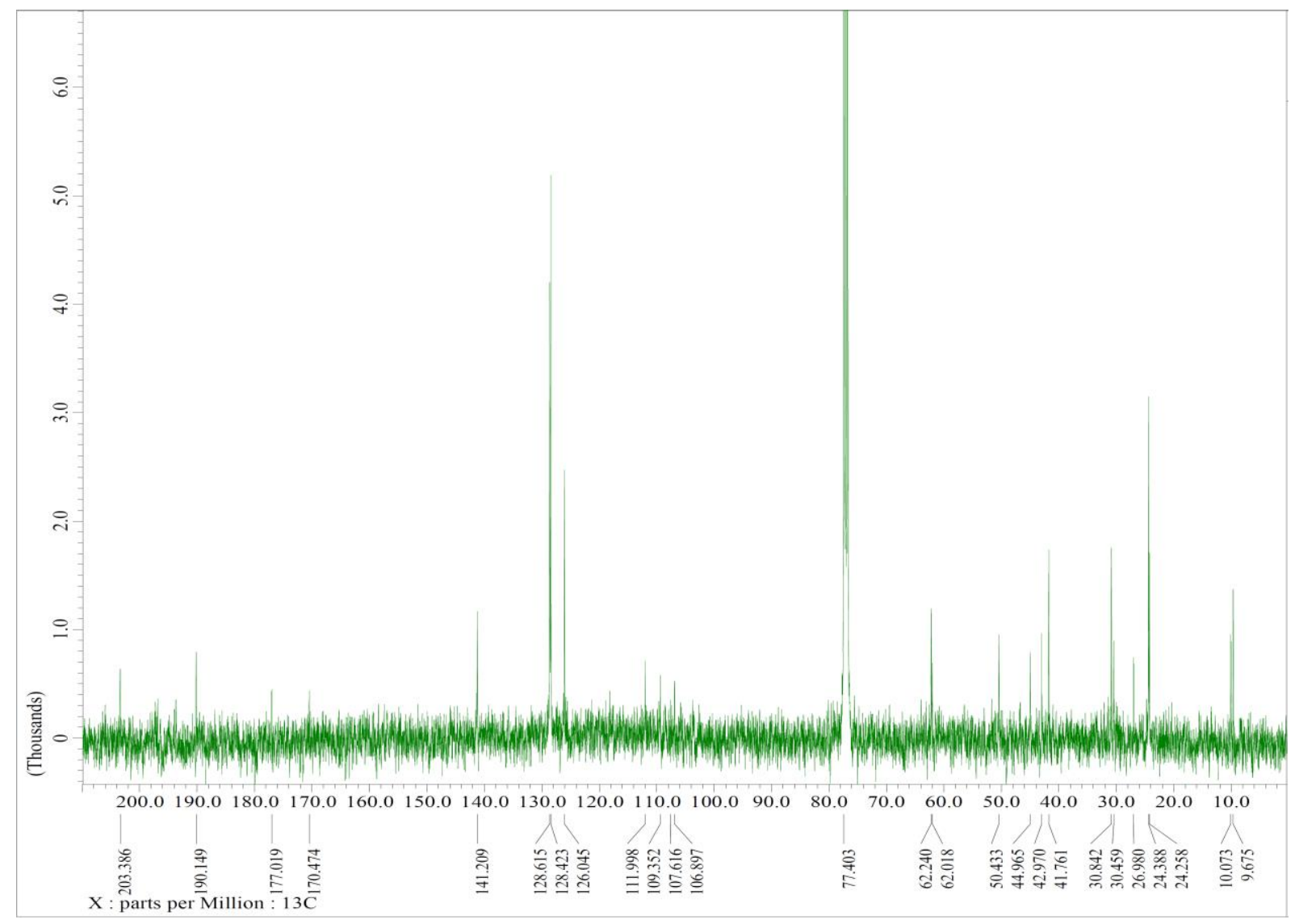


Figure SI-1 : Emission spectrum of the Philips Tubes filtered by the Pyrex reactor

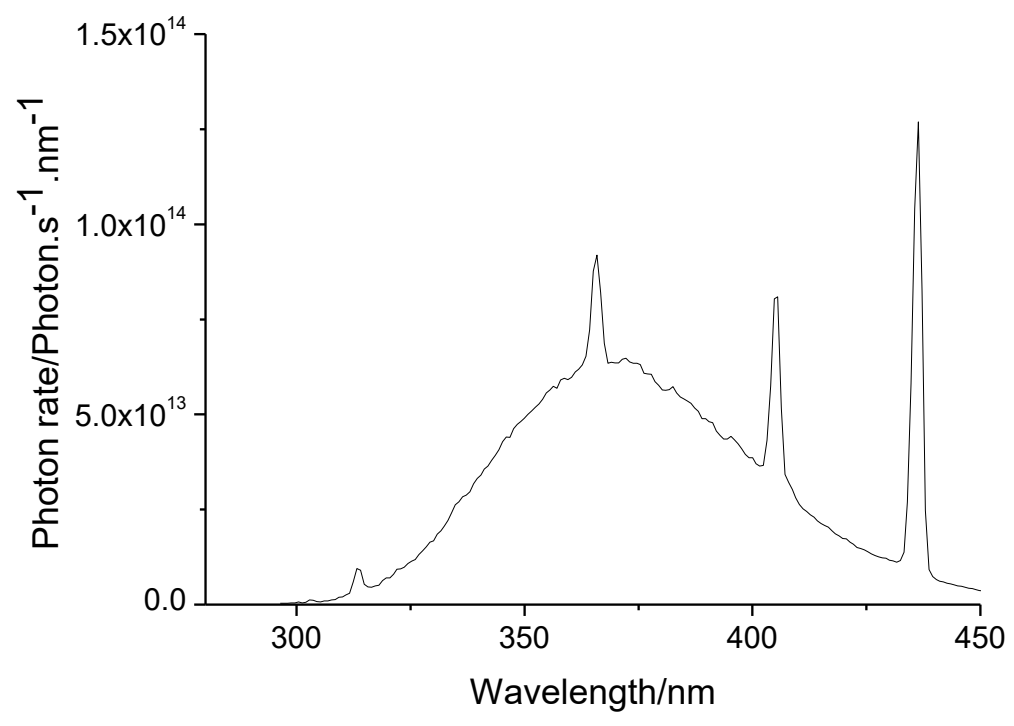


Figure SI-2 : Myrigalone A photodegradation after 30 min of irradiation in water :acetonitrile $(90: 10, \mathrm{v} / \mathrm{v})$. Percentage of degradation vs initial myrigalone concentration

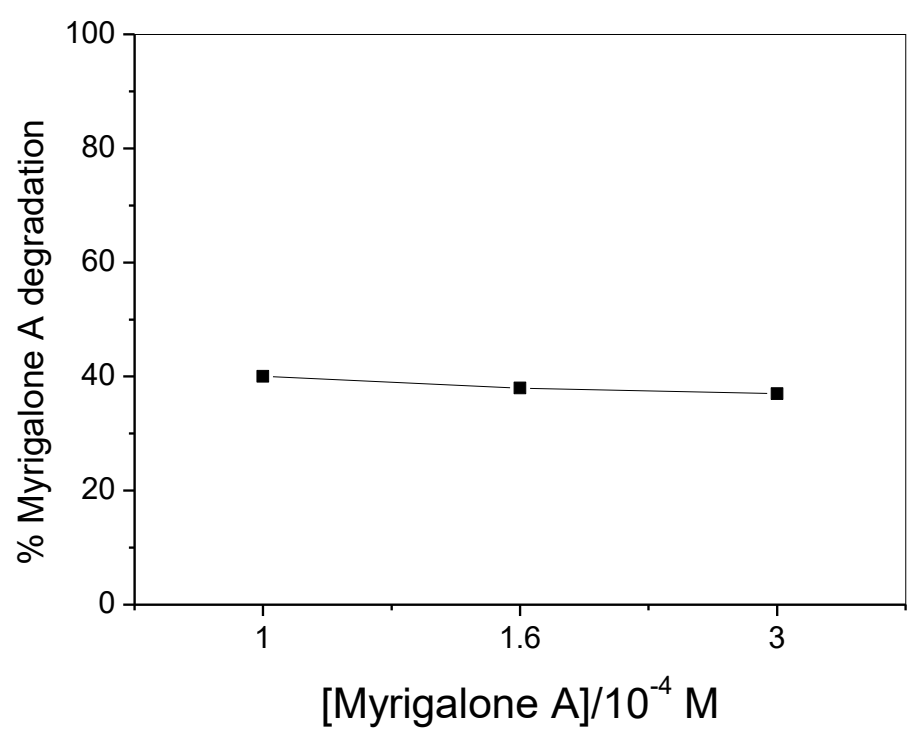


Figure SI-3 : Typical HPLC chromatogram obtained after of $1 \mathrm{~h}$ of irradiation in water :acetonitrile $(90: 10, \mathrm{v} / \mathrm{v})$

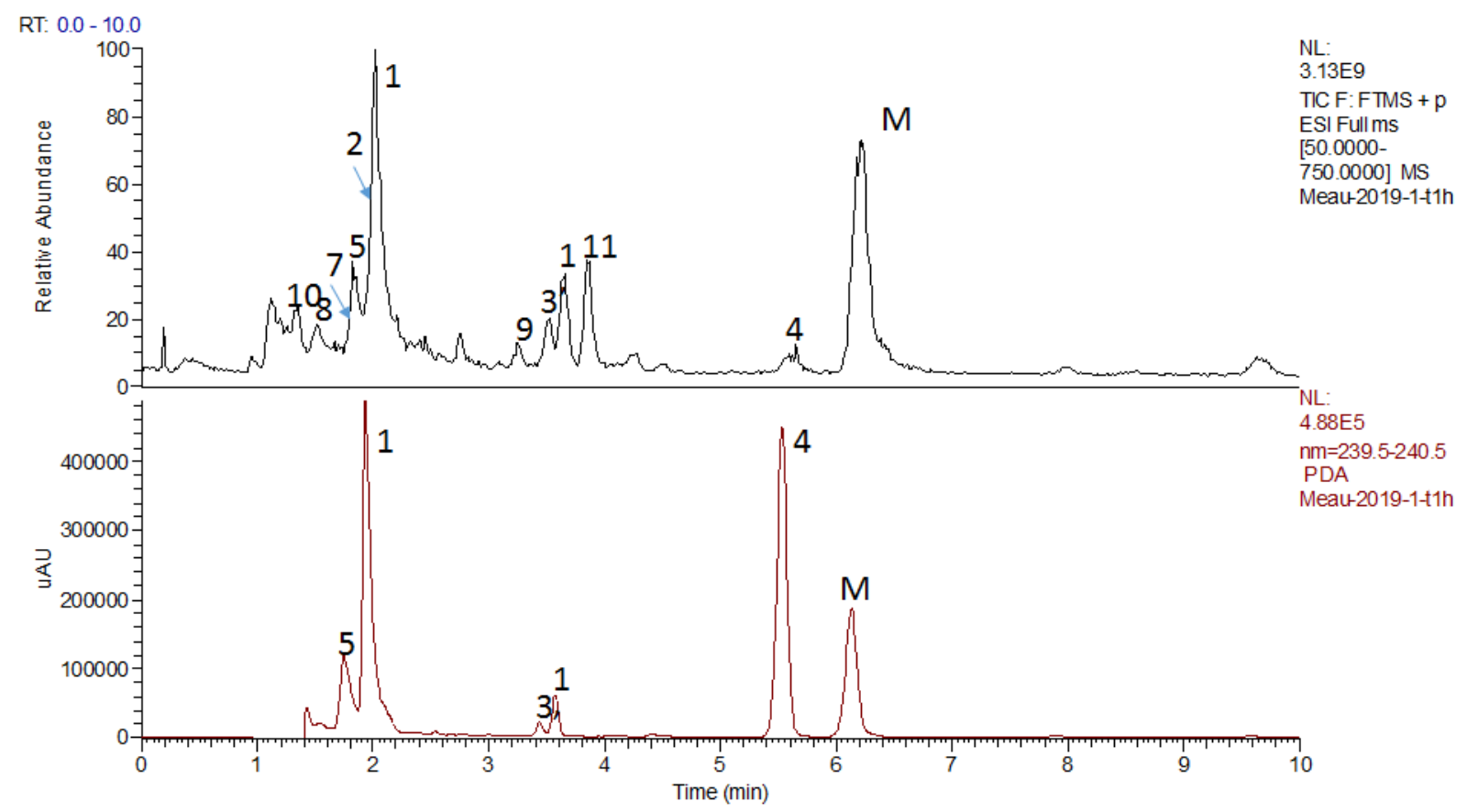


Figure SI-4: MS-MS analysis of the main photoproducts

C:IUsers \...Meau-2019-1-t1h-MSMk

01/08/19 19:51:51

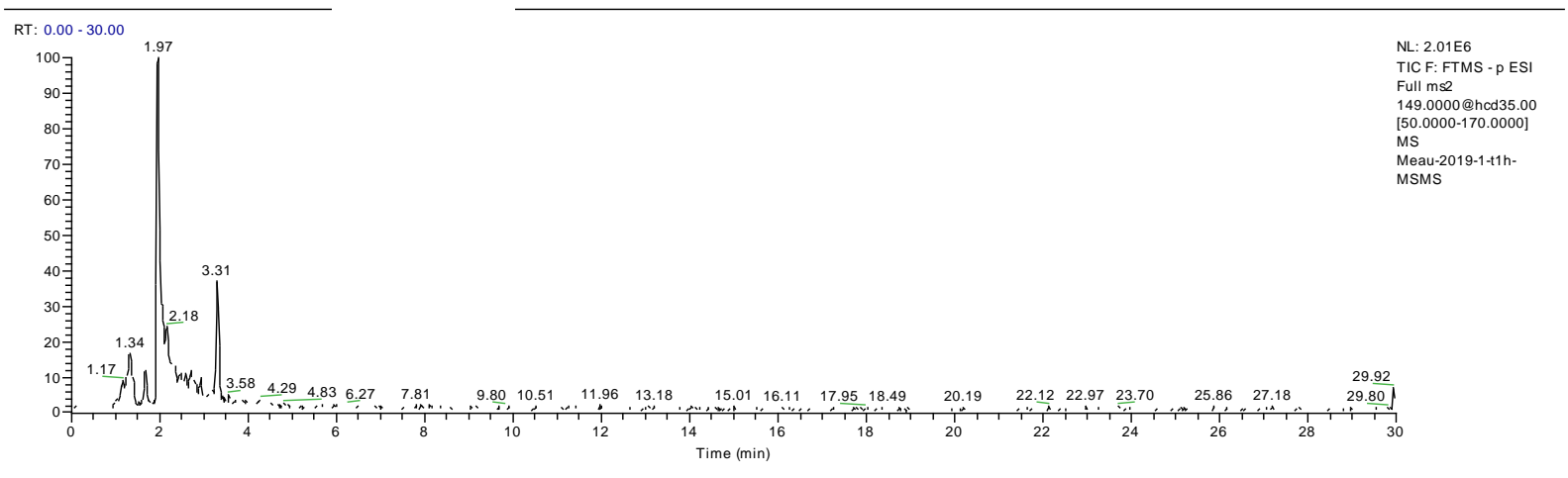

Meau-2019-1-t1h-MSMS \#573 RT: 1.97 AV: 1 NL: 1.75E6
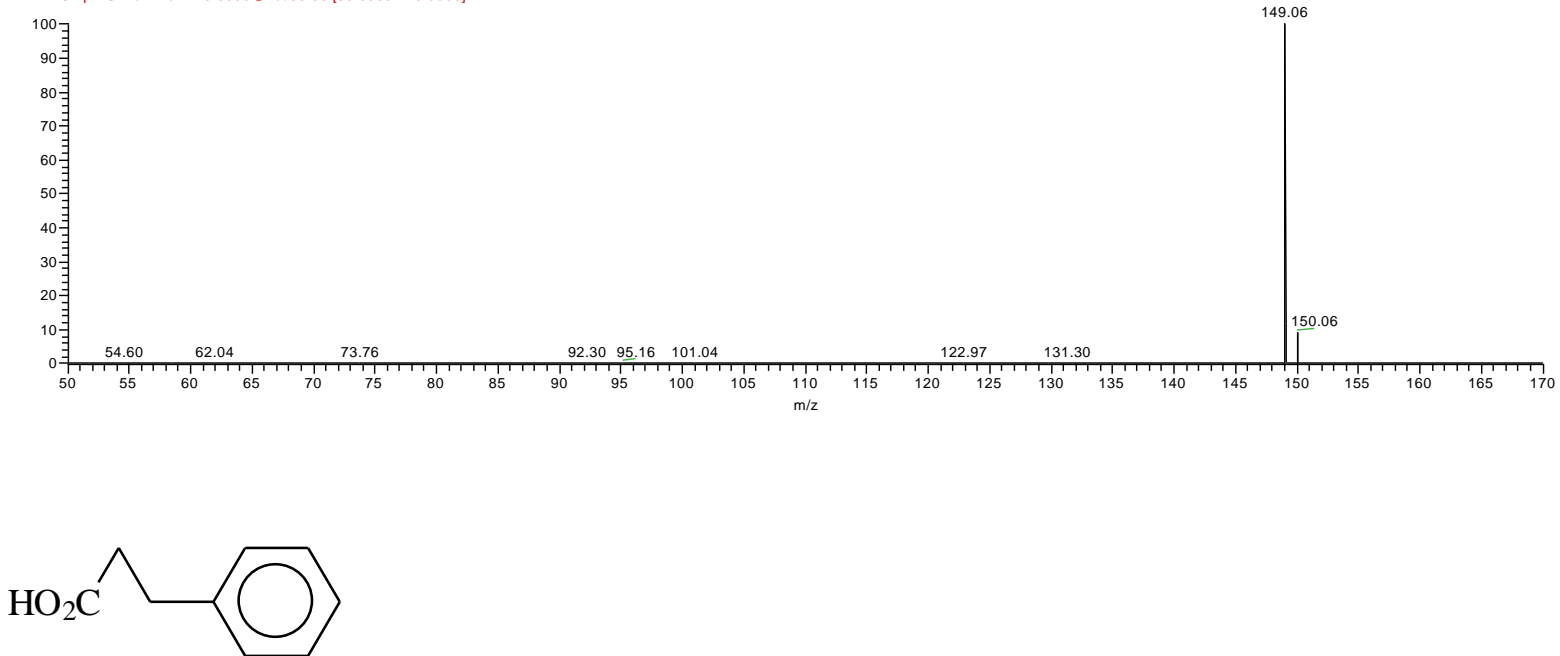


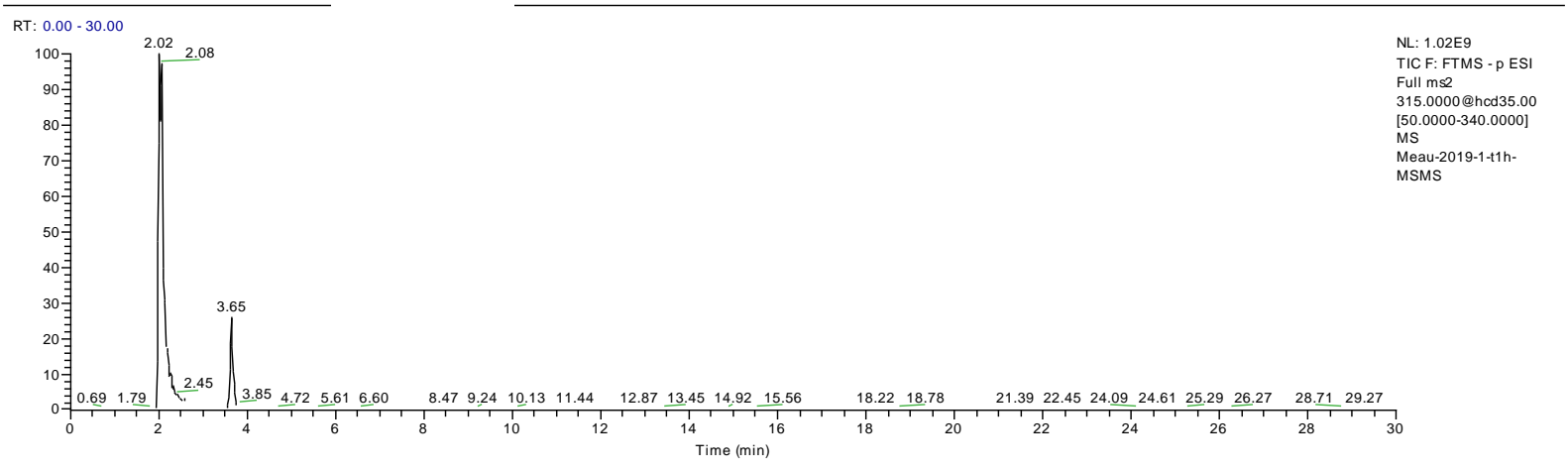

Meau-2019-1-t1h-MSMS \#613 RT: 2.10 AV: 1 NL: $1.03 E 8$
F: FTMS - p ESI Full ms2 $315.0000 @$ hod 35.00 [50.0000-340.0000]

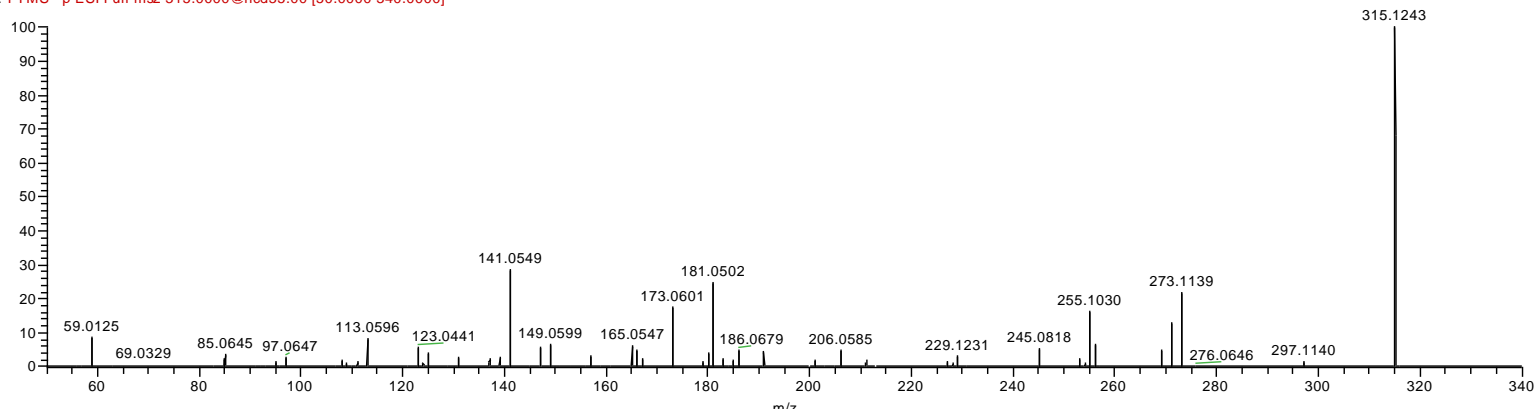<smiles>CC1(C)C(=O)C(C)(O)C(=O)C(C(=O)CCc2ccccc2)=C1O</smiles> 


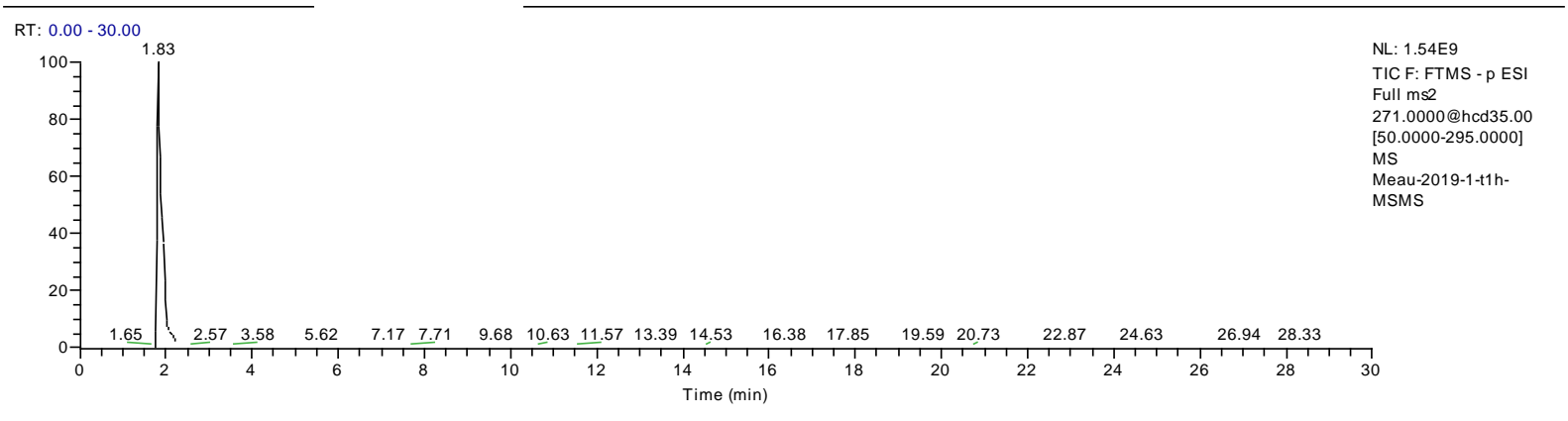

Meau-2019-1-t1h-MSMS \#550 RT: 1.89 AV: 1 NL: $5.47 E 8$

F: FTMS - p ESI Full ms2 271.0000@hcd35.00 [50.0000-295.0000]

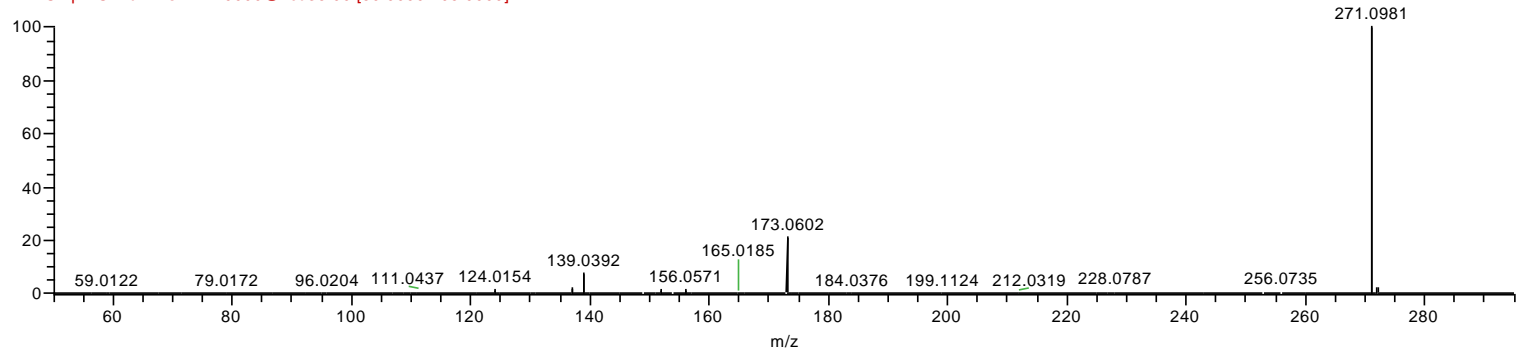<smiles>CC1(C)C(=O)C(O)=C(/C(O)=C\Cc2ccccc2)C1=O</smiles> 


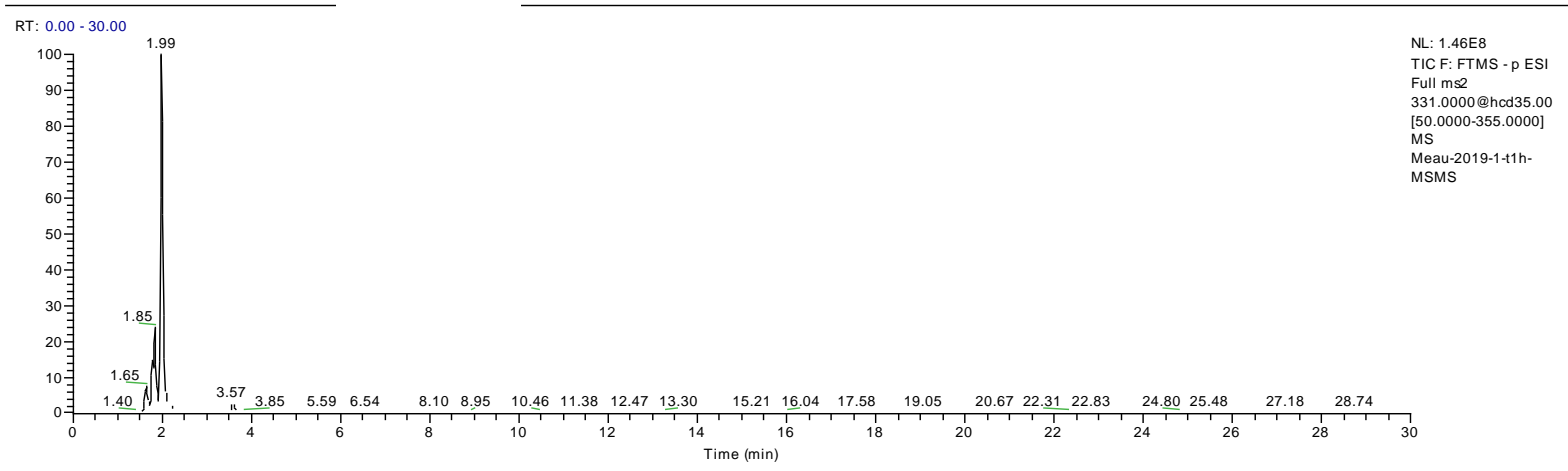

Meau-2019-1-t1h-MSMS \#584 RT: 2.01 AV: 1 NL: $2.73 E 7$
F: FTMS - p ESI Full ms2 $331.0000 @$ hod 35.00 [50.0000-355.0000]

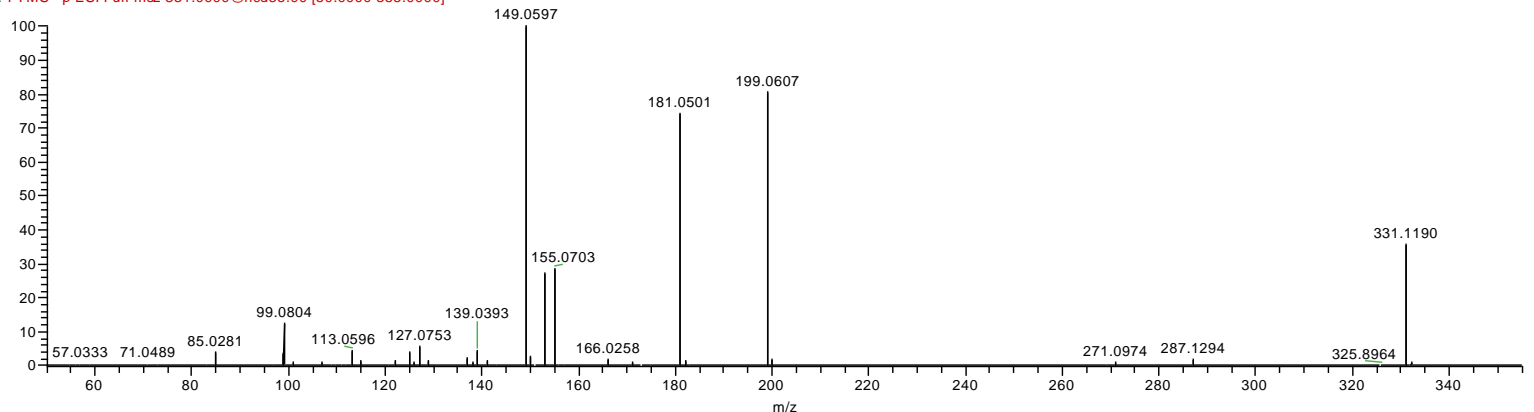<smiles>CC1(C)C(=O)C(C)(O)C(O)(C(=O)CCc2ccccc2)C(O)=C1O</smiles> 


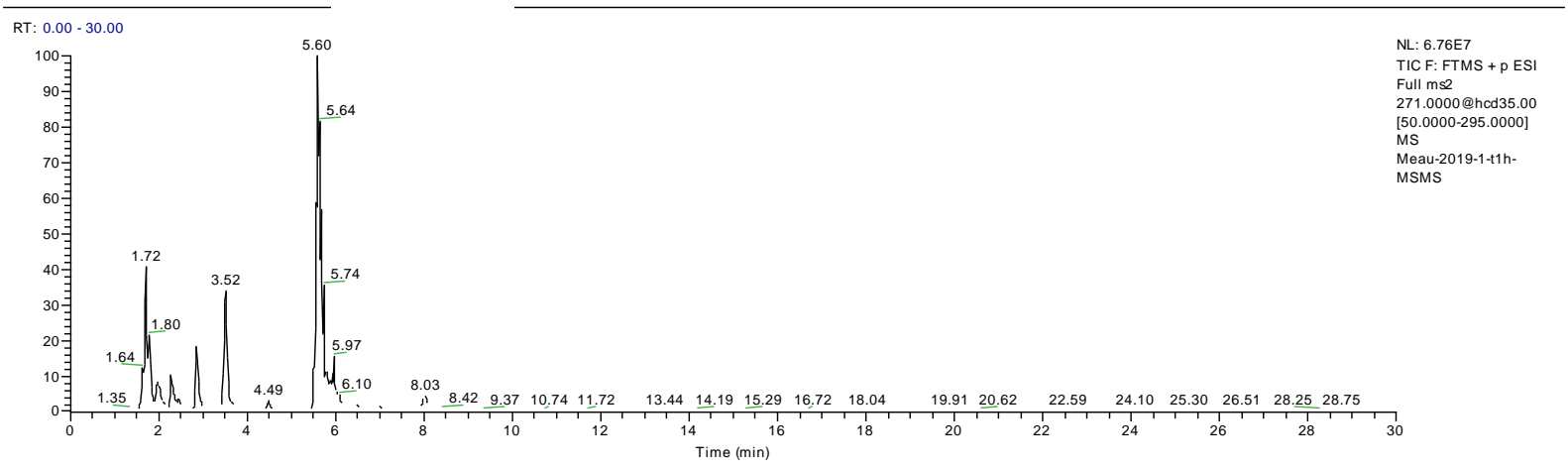

Meau-2019-1-t1h-MSMS \#1643 RT: 5.60 AV: 1 NL: 3.24 E7
F: FTMS + p ESI Full ms2 271.0000@hcd35.00 [50.0000-295.0000]

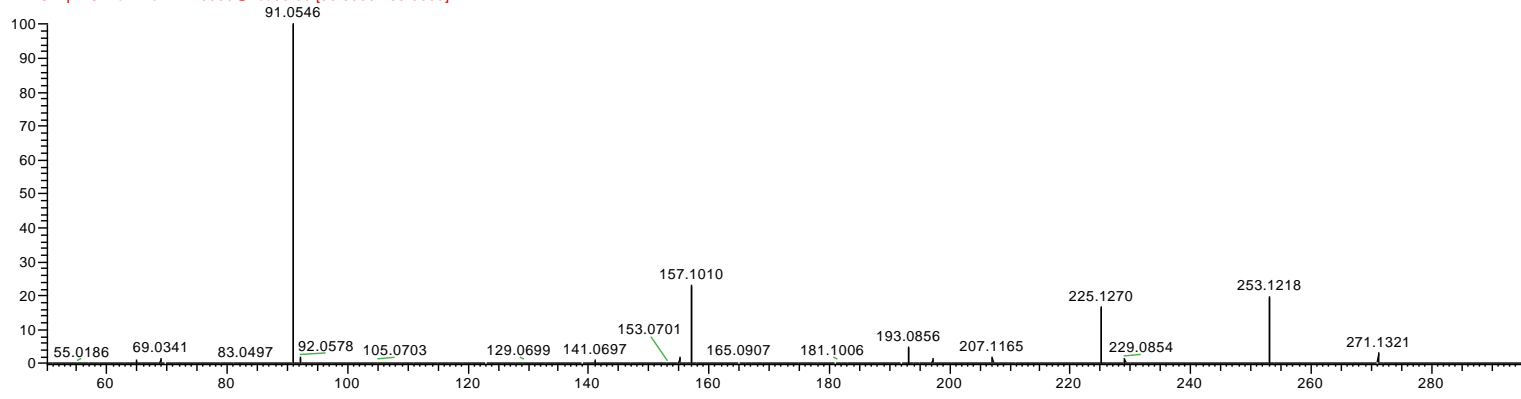

$\mathrm{m} / \mathrm{z}$<smiles>CC1=C(C(=O)CCc2ccccc2)C(=O)C(C)(C)C1=O</smiles> 


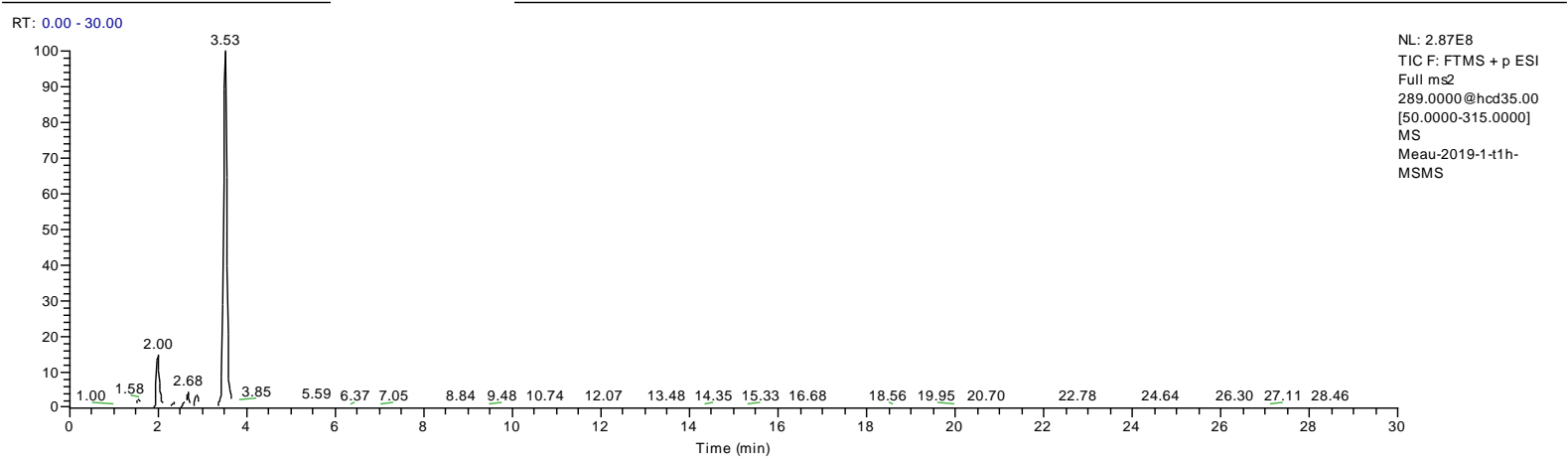

Meau-2019-1-t1h-MSMS \#1032 RT: $3.51 \quad$ AV: 1 NL: 3.74 E7
F: FTMS + p ESI Full ms2 289.0000@hcd35.00 [50.0000-315.0000]

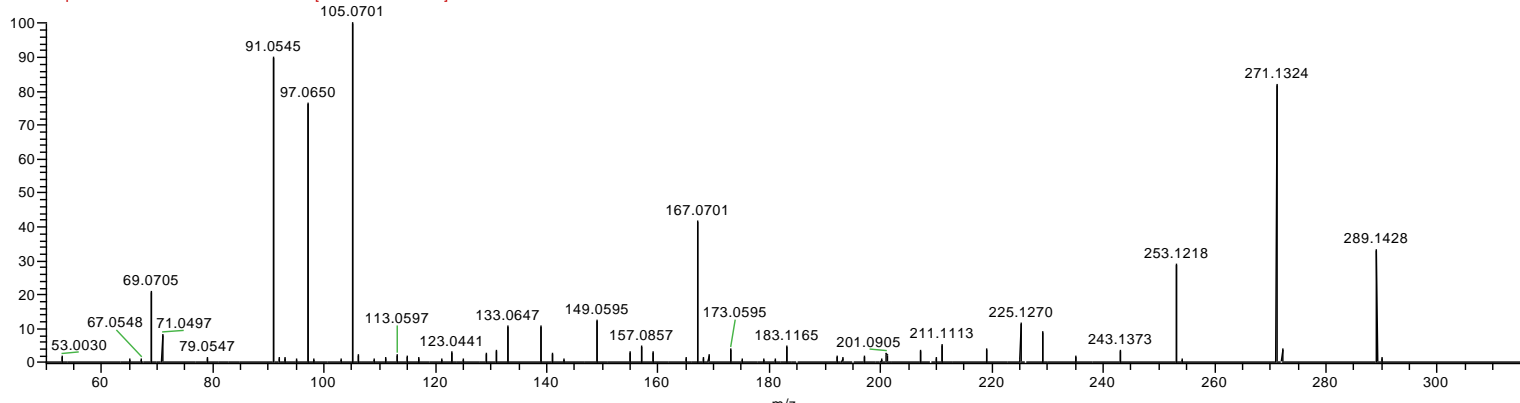<smiles>CC1(C)C(=O)C(C)(O)C(C(=O)CCc2ccccc2)=C1O</smiles> 
Figure SI-5: Kinetics of photoproducts formation in water: acetonitrile (90:10)

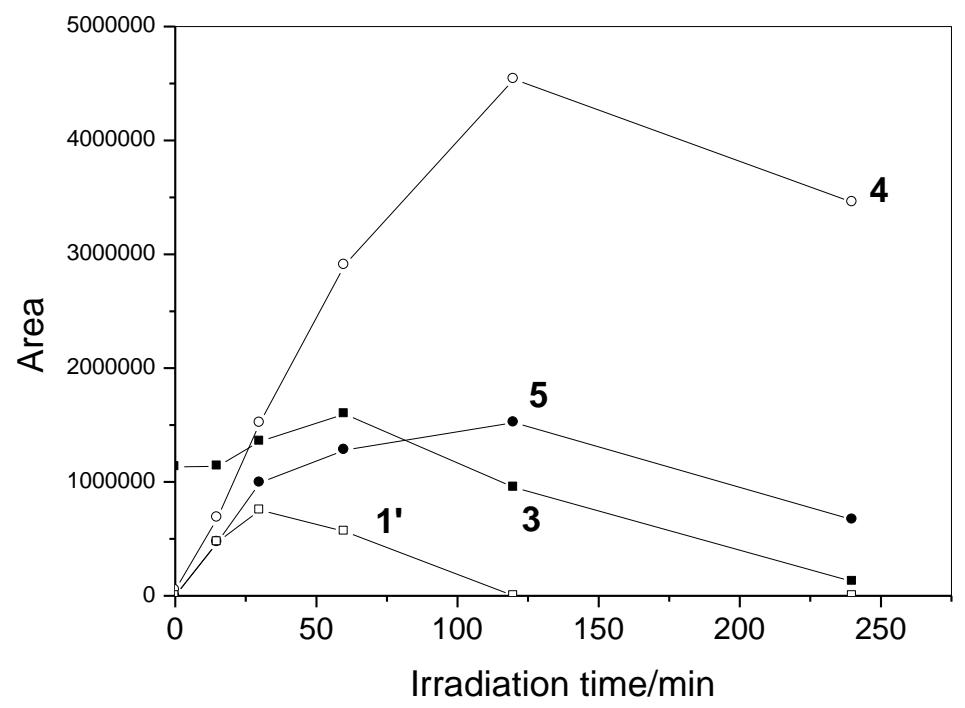


Figure SI-6: HPLC-HRMS chromatograms of 90-min irradiated solutions of myrigalone $\left(10^{-4}\right.$ $\mathrm{M})+$ germacrone $\left(10^{-4} \mathrm{M}\right)(\mathrm{A})$ and of germacrone $\left(10^{-4} \mathrm{M}\right)$ alone $(\mathrm{B})$

A)

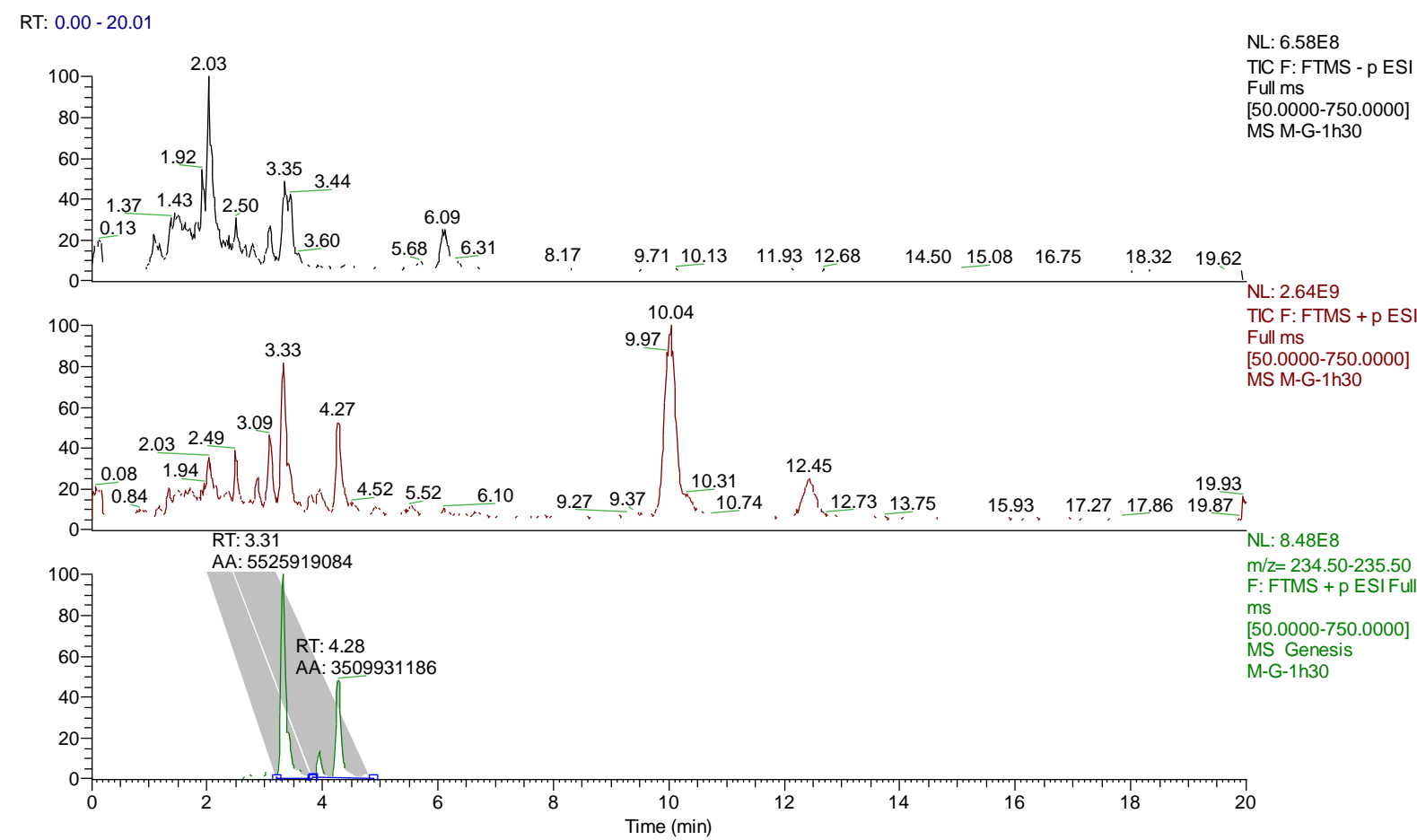

B)

RT: $0.00-20.01$

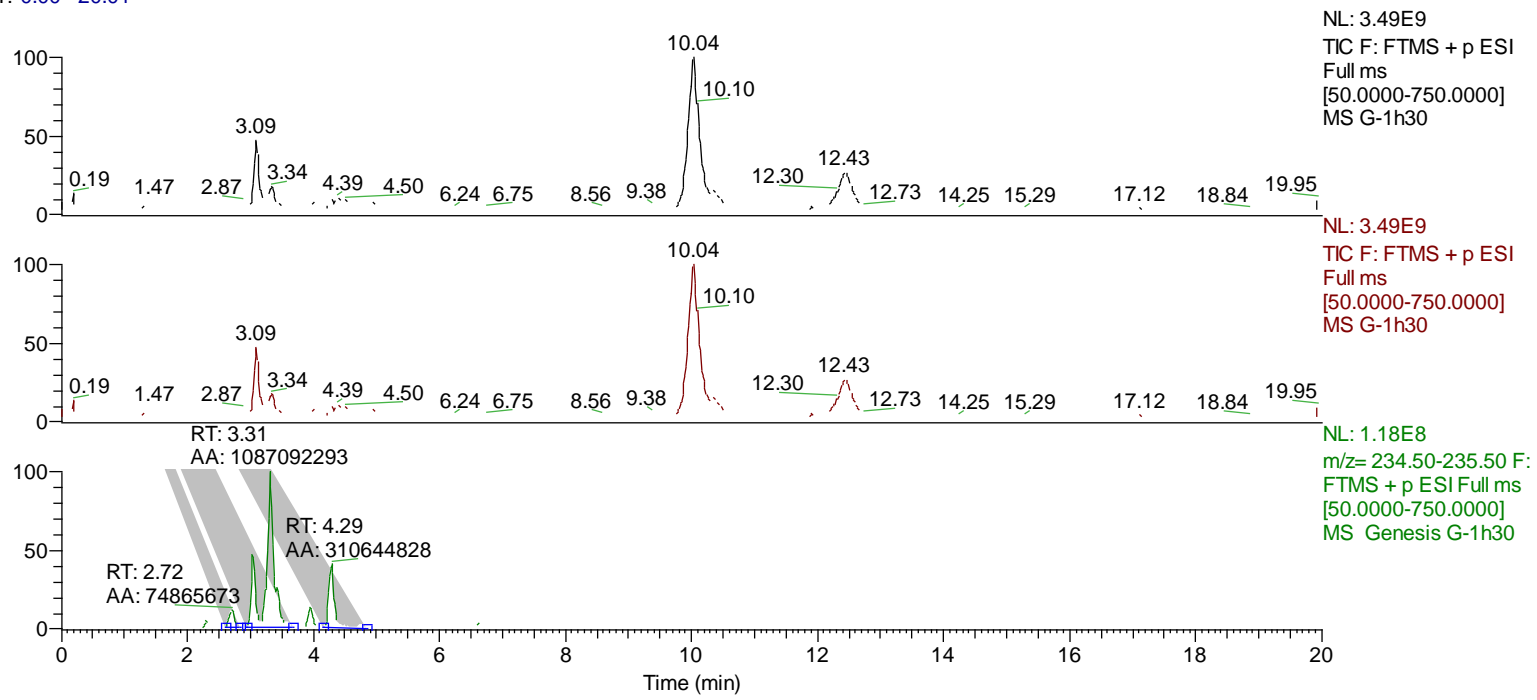

